Beyond Environmental Law: Policy Proposals for a Better Environmental Future, Alyson Flournoy and David Driesen, eds. (Cambridge University Press, forthcoming 2010)

Chapter: The Constitution and Our Debt to the Future

April 11, 2009

Copyright 2009 by Rena Steinzor--Please do not cite, quote, or copy without express permission of author.

\title{
The Constitution and Our Debt to the Future
}

\author{
By Rena Steinzor ${ }^{1}$
}

ABSTRACT: Health and safety laws have always been justified as manifestations of congressional authority to regulate and protect the free flow of interstate commerce under Article I, section 8 of the Constitution. Professor Steinzor argues that reliance on the Commerce Clause can support next generation proposals, including a National Environmental Legacy Act proposed by Professor Alyson Flournoy, which would require that any action on federal land involving the consumption or destruction of resources must be sustainable, as well as pending climate change legislation. But, Steinzor says, a far more desirable constitutional foundation for such laws is the General Welfare Clause found in Article I, section 8. The Commerce Clause has the important deficit of focusing on commercial transactions between two entities now in existence, while next generation laws must focus on the preservation of natural resources for us by future generations not now in existence. Steinzor argues that the Supreme Court has long recognized a state "police power" to protect public health and preserve the general welfare outside the constricting context of commercial transactions. The Court could and should read an analogous federal police power into the General Welfare clause given global threats such as climate change. She locates her proposal in work on the concept of an affirmative constitution by Professor Robin West, among others.

\section{Part I: A New Breed of Public Law}

Congress gave birth to the nation's major federal environmental statutes during a period of intense and extraordinarily fertile social upheaval, as America’s young people struggled to reclaim their government and parents fought to recover their children's respect. The first generation of statutes, passed as the Vietnam War was winding down, launched a forty-year revolution in the way Americans treat their environment. These statutes, amended and

\footnotetext{
${ }^{1}$ As I was midway through writing this chapter, I learned to my delight that its central thesis is not original. My wonderful colleague, Tulane Professor Oliver Houck, proposed in a lecture at Pace University Law School that environmentalists-especially those concerned about the preservation of natural resources—shift the historical emphasis on the Commerce Clause to the General Welfare Clause for many of the same reasons I advance here. Oliver Houck, Environmental Law and the General Welfare, 16 PACE ENVTL. L. REV. 1 (1998-1999). I am also grateful to my colleagues at the University of Maryland School of Law who helped me develop this proposal at one of our aptly named "half-baked ideas" lunches, including Mark Graber, Robert Percival, Jana Singer, Max Stearns Peter Quint, Bill Reynolds, Michael Van Alstine, and Greg Young. I also thank Alyson Flournoy, Catherine O’Neill, Lisa Heinzerling, and Sidney Shapiro for their help and encouragement. Natalie Baughman, Ryan Severson, and Limor Weizmann provided excellent research assistance.
} 
Beyond Environmental Law: Policy Proposals for a Better Environmental Future, Alyson Flournoy and David Driesen, eds. (Cambridge University Press, forthcoming 2010)

Chapter: The Constitution and Our Debt to the Future

April 11, 2009

Copyright 2009 by Rena Steinzor--Please do not cite, quote, or copy without express permission of author.

strengthened many times, propelled unprecedented advancements in pollution control and the preservation of natural resources.

Yet somewhere along the line - it is difficult to pinpoint a single event or moment - this progress began to unravel. We learned that the environment of our country was irrevocably linked to the global environment and that frightening changes were underway in the atmosphere as an overload of fossil fuel and other emissions disrupted the planet's climate. The developing world was intent on catching up with the United States and Europe economically but lacked the regulatory infrastructure to moderate the impact of industrialization. The United States backed away from global leadership on environmental issues because energy producers convinced politicians that this role cost too much.

These fateful decisions could not have come at a worst time, as we are belatedly beginning to realize. The world confronts accelerating climate change, an environmental crisis that makes efforts to conquer previous challenges look like mere dress rehearsals. So much has changed - globalization of business, invention of the worldwide web, discovery of the human genome - and yet so much has remained the same - disillusionment with government, the false dichotomy of jobs versus environment, the overpowering resistance of corporations to regulation. We strain to find ways for our weakened government institutions - from Congress to the president to the career civil service -- to steer the nation out of these blind alleys and back onto the high road.

As the chapters in this volume argue, the reforms necessary to meet these grave challenges must go "beyond environmental law" to a conceptual plane where even the most basic and routine assumptions are revisited. To recreate the atmosphere of revolutionary change that 
Beyond Environmental Law: Policy Proposals for a Better Environmental Future, Alyson Flournoy and David Driesen, eds. (Cambridge University Press, forthcoming 2010)

Chapter: The Constitution and Our Debt to the Future

April 11, 2009

Copyright 2009 by Rena Steinzor--Please do not cite, quote, or copy without express permission of author.

gave birth to modern environmental protection, we must push beyond incremental tinkering.

New ideas must be incubated, embraced, enacted, and implemented.

The National Environmental Legacy Act (NELA) proposed by Professor Alyson

Flournoy in the first chapter of this book qualifies as such a breakthrough approach because it would compel us to lengthen the temporal framework of decisionmaking into the indefinite future and reject actions that would make humankind's consumption of natural resources unsustainable over that long run. NELA would prohibit any use of federally owned property unless the full gamut of natural resources that exist on that land could be replenished in time for future generations to use them. Activities on privately owned land that could destroy natural resources on federal property would also be prohibited. Professor Flournoy proposes a fiftyyear time horizon for the evaluation of the activities covered by NELA, acknowledging that this period is arbitrary and could be longer or shorter. However, she clearly considers this goal to need constant refreshment, with sustainability reevaluated on an enduring basis through an iterative cycle of decision-making.

Similarly, President Barack Obama and Democratic leaders in Congress have embarked on an effort to pass climate change legislation centered on proposals to impose indefinite limits on carbon emissions through a "cap and trade" system. ${ }^{2}$ The system would either sell or give legal permission to anthropogenic sources of "greenhouse gases" to emit a certain number of tons each year. Such permission--also referred to as pollution “credits" or "allowances"--would not be construed as property rights, at least by the legislature, and would be subject to a cap on

\footnotetext{
2 The White House, President Barack Obama, The Agenda: Energy and the Environment, available at http://www.whitehouse.gov/agenda/energy and_environment/ (visited on March 24, 2009); Patrick O'Connor, "Waxman Makes Climate Change Mark," Politico (March 9, 2009), available at http://www.politico.com/news/stories/0309/19768.html (visited on March 24, 2009).
} 
Beyond Environmental Law: Policy Proposals for a Better Environmental Future, Alyson Flournoy and David Driesen, eds. (Cambridge University Press, forthcoming 2010)

Chapter: The Constitution and Our Debt to the Future

April 11, 2009

Copyright 2009 by Rena Steinzor--Please do not cite, quote, or copy without express permission of author.

the total amount of annual emissions. Entities that possessed allowances could sell or otherwise trade them to entities that do not. The system would exist indefinitely.

The context and ramifications of the activities that fall within NELA's jurisdiction are both larger and smaller than the policy choices we must make with respect to climate change. Conceivably—although it is admittedly hard to imagine at this troubled juncture in human affairs—we could reduce carbon emissions to the point that the worst consequences of climate change are prevented. But even if we managed such a remarkable accomplishment, we would still be left with the difficult job of preserving the sustainability of the natural resources covered by NELA. In that sense, NELA is bigger than climate change regulation. Yet climate change reductions must be garnered from sources located everywhere in the United States (and, ultimately, the world), not just federal lands, and may well provoke more significant realignments in the way people live than NELA would ever produce. In that sense, NELA is smaller.

Regardless, both initiatives are sufficiently ambitious in scope and nature, and mark such a giant step forward in the design of environmental law, that they raise some profound legal issues. This chapter addresses the most fundamental question in American law: how should we read the U.S. Constitution to justify these brave new breeds of environmental law? In a nutshell, I argue that we should reexamine historical interpretations of Congress' constitutional authority to protect the environment. Instead of justifying federal intervention as a product of the national government's interest in fostering interstate commerce or guarding the government's property rights, these activities are better viewed as a manifestation of federal authority to safeguard and promote the general welfare of the country and its populace. 
Beyond Environmental Law: Policy Proposals for a Better Environmental Future, Alyson Flournoy and David Driesen, eds. (Cambridge University Press, forthcoming 2010)

Chapter: The Constitution and Our Debt to the Future

April 11, 2009

Copyright 2009 by Rena Steinzor--Please do not cite, quote, or copy without express permission of author.

Federal environmental laws, along with all the other statute that assign the national government a role over public health and safety, are assumed to be based on Article I, section 8 of the Constitution, commonly known as the "Commerce Clause,” which reads: "The Congress shall have Power ... To regulate Commerce with foreign Nations, and among the several States, and with the Indian Tribes.”3 According to the dictionary, the word "commerce” has two different meanings: its root definition is the "interchange of ideas, opinions, or sentiment between individuals and groups in society,” but its most common usage is to describe the “exchange or buying and selling of commodities." 4 As Congress expanded the federal government's reach into areas of public law long dominated by the states, the Supreme Court kept pace, broadening its interpretation of the Commerce Clause to encompass activity that could potentially affect the economy, whether or not those activities actually involved the exchange of money. ${ }^{5}$

This jurisprudence is arguably broad enough to encompass NELA and climate change. NELA has additional constitutional support in Article IV, Section 3, giving the federal government authority to manage land it owns. ${ }^{6}$ Why, then, cause trouble by proposing that we would do better to look at other portions of the Constitution-specifically, the power to tax and spend for the general welfare ${ }^{7}$--for authority to support new laws?

\footnotetext{
${ }^{3}$ U.S. Const., art. I, §8. The Constitution further states that "[a]ll legislative powers herein granted shall be vested in a Congress of the United States.” U.S. CONST., art. I, §1.

${ }^{4}$ WEBSTER's ThiRd NEW INTERNATIONAL DictionARY OF THE ENGLiSH LANGUAGE (Unabridged) (Philip Babcock Gove, Ph.D, and the Merriam-Webster Editorial Staff, eds.) (1993) at 456.

${ }^{5}$ For a description of these developments, see ERWIN CHEMERINSKY, CONSTITUTIONAL LAW PRINCIPLES AND POLICIES at 254-75 (3d ed.) (2006).

${ }^{6}$ U.S. CONST., art. I, $\S 3$.

${ }^{7}$ U.S. CONST., art. I, §8.
} 
Beyond Environmental Law: Policy Proposals for a Better Environmental Future, Alyson Flournoy and David Driesen, eds. (Cambridge University Press, forthcoming 2010)

Chapter: The Constitution and Our Debt to the Future

April 11, 2009

Copyright 2009 by Rena Steinzor--Please do not cite, quote, or copy without express permission of author.

Despite the Supreme Court’s broad interpretation of the Commerce Clause to justify

federal intervention into most Americans' daily activities, rooting environmental law in the analysis of economic effects has constricted its growth to an unrecognized and corrosive extent. The long-standing assumption that the pros and cons of environmental policy must be rationalized in terms of money reached a point of diminishing returns about three decades ago, with the militant application to cost-benefit analysis to regulatory decisions. Supporters of America's strong laws reacted instinctively to these developments by attacking that methodology on its own terms. ${ }^{8}$ But for perfectly understandably reasons, it did not occur to us to think about whether our tacit acceptance of the Commerce Clause as the constitutional foundation for environmental and other health and safety laws could be the genesis of these disheartening developments.

This chapter begins an inquiry into the implications of those constitutional roots. At first and maybe even at second blush, my reasoning will appear to push against the strong tide of immutable constitutional theory when reformers of environmental law have much more pressing and immediate work to do. But I am convinced that this apparently quixotic exercise is well

\footnotetext{
${ }^{8}$ See, e.g., Sidney A. Shapiro \& Christopher H. Schroeder, Beyond Cost-Benefit Analysis: A Pragmatic Reorientation, 32 Harv. EnvTL. L. Rev. 433 (2008); Douglas A. Kysar, Discounting . . On Stilts, 74 U. CHI. L. Rev. 119 (2007); Rena I. STEINZOR, Mother EARTH AND UnCle SAM: How POLLUTION AND Hollow GOVERNMENT HURT OUR KIDS (Univ. of Texas 2007); Frank Ackerman, The Unbearable Lightness of Regulatory Costs, 33 Fordham URB. L.J. 1071 (2006); David M. Driesen, Is Cost-Benefit Neutral?, 77 Colo. L. ReV. 335 (2006) and Distributing the Costs of Environmental, Health, and Safety Protections: The Feasibility Principle, CostBenefit Analysis, and Regulatory Reform, 32 B.C. EnVTL. AfF. L. REV. 1 (2005); Robert R.M. Verchick, The Case Against Cost-Benefit Analysis, 32 Ecology L. Q. 101 (2005); FrAnK ACKERMAN \& LisA HEINZERLing, Priceless: On KNowing the Price Of Everything and the Value Of Nothing (New Press 2004); Catherine A. O’Neill, Mercury, Risk, and Justice, 34 ENVTL. L. REP. 11,070 (2004); THOMAS O. MCGARITY, SIDNEY A. SHAPIRO, \& DAvid Bollier, Sophisticated SABOtage (Envtl. L. Inst., 2004); Amy Sinden, Cass Sunstein's Cost-Benefit Lite: Economics for Liberals, 29 ColumB. J. EnVTL. L. 191 (2004); Thomas O. McGarity, Professor Sunstein's Fuzzy Math, 90 GeO. L. J. 2341 (2002); Lisa Heinzerling, Regulatory Costs of Mythic Proportions, 107 YALE L.J. 1981 (1998) and The Rights of Statistical People, 24 Harv. ENVTL. L. REV. 189 (2000).
} 
Beyond Environmental Law: Policy Proposals for a Better Environmental Future, Alyson Flournoy and David Driesen, eds. (Cambridge University Press, forthcoming 2010)

Chapter: The Constitution and Our Debt to the Future

April 11, 2009

Copyright 2009 by Rena Steinzor--Please do not cite, quote, or copy without express permission of author.

worth the effort. The widespread tendency in recent years to employ economics as the primary lens through which we justify health, safety, and environmental regulation has turned the missions of the major environmental laws on their heads, compelling us to consider whether the marketplace will address the problem, as opposed to whether and to what extent the government has responsibility for protecting the public health and the environment.

Americans count on their government to prevent a growing number of international disasters - from bird flu to global terrorism to water shortages -and do not conceive of these protections as justified only with respect to "free market," economic concerns. Not only did the Framers of the Constitution recognize these expectations, they embraced them in Article 1, Section 8, which authorizes Congress to "provide for the general Welfare" by taxing, spending, and making all "necessary and proper" laws. ${ }^{9}$

I also argue that if commerce at its most fundamental level is comprised of the exchange of commodities and money, then the term refers to a "marketplace" at a specific point in time. Yet ideas like preserving natural resources for future generations or otherwise preventing pollution that could harm our children and their children demand a significantly more attenuated frame of temporal reference than has applied to the more immediate interventions that characterize much of environmental law.

Part II of this chapter considers the implications of efforts by the judiciary and the Executive Branch to apply the Commerce Clause to environmental law. Part III explains why the General Welfare Clause, read in conjunction with the Constitution's Preamble, could liberate our search for breakthrough alternatives, drawing on precedents that support the exercise by the

${ }^{9}$ U.S. CONST., art. I, §8. 
Beyond Environmental Law: Policy Proposals for a Better Environmental Future, Alyson Flournoy and David Driesen, eds. (Cambridge University Press, forthcoming 2010)

Chapter: The Constitution and Our Debt to the Future

April 11, 2009

Copyright 2009 by Rena Steinzor--Please do not cite, quote, or copy without express permission of author.

states of a "police power" to protect the public's health. Part IV locates these ideas in the scholarly literature that has developed the idea of an affirmative--or aspirational--Constitution.

\section{Part II: The Commerce Clause, the Market, and Discounting the Future}

\section{A. Commerce Clause Jurisprudence}

The Supreme Court has embraced an expansive definition of Congress' Commerce Clause authority, keeping step with national political developments that expanded the federal role in every aspect of domestic policy, beginning with the New Deal and reaching an apex in the Vietnam War/Watergate era. ${ }^{10}$ The furthest reaches of the test ultimately developed by the Court had two crucial elements: (1) the activities Congress sought to regulate could involve "noneconomic" transactions so long as (2) those activities had a "substantial” effect on interstate commerce. ${ }^{11}$ The Court was more willing to curtail Congress when it perceived that the federal government was manhandling the states. For example, it outlawed federal attempts to “commandeer" state government resources in New York v. United States, a case involving the siting of a low-level radioactive waste facility. ${ }^{12}$ But because all major environmental laws afford the states the opportunity to volunteer to assume delegated authority to implement federal regulatory requirements, and sweeten the deal with grants to support those state programs, New York v. United States seemed to address an extreme example of federal overreaching without much significance for the future.

\footnotetext{
${ }^{10}$ For an excellent discussion of these developments in the context of environmental protection, see Robert V. Percival, "Greening” the Constitution-Harmonizing Environmental and Constitutional Values, 32 ENVTL. L. 809 (2002) [hereinafter Percival].

${ }^{11}$ See, e.g., Wickard v. Fillburn, 317 U.S. 111, 127-28 (1942).

12505 U.S. 144 (1992).
} 
Beyond Environmental Law: Policy Proposals for a Better Environmental Future, Alyson Flournoy and David Driesen, eds. (Cambridge University Press, forthcoming 2010)

Chapter: The Constitution and Our Debt to the Future

April 11, 2009

Copyright 2009 by Rena Steinzor--Please do not cite, quote, or copy without express permission of author.

The 1995 decision in United States v. Lopez shook complacency about the federal penchant for inventing elaborate regulatory programs and foisting them off on state agencies to enforce. ${ }^{13}$ The case involved a search for guns in a high school senior's locker in order to provide evidence for a criminal case under the federal Gun-Free School Zones Act of 1990. In a tense, 5-4 majority opinion, Chief Justice Rehnquist argued that the Act had "nothing to do with 'commerce' or any sort of economic enterprise” and that it did not contain any self-limiting jurisdictional provision ensuring its limited application to activities that substantially affected commerce. ${ }^{14}$ Justice Breyer’s dissent gave full-throated voice to the liberal justices’ view that the opinion was a startling departure from precedent. Chiding the majority for shifting direction on the Court's long-standing and expansive definitions of commerce, he warned that its effort to distinguish between "economic" and "non-economic" activity would not only create turmoil in the lower courts, but also involve judges in second-guessing Congress in ways that exceeded their appropriate constitutional role. ${ }^{15}$

Despite these warnings, the dissent's supporters in the academy and in practice could read Lopez as confined to federal incursions into the traditionally state-dominated realm of criminal enforcement. They could reasonably argue that if Congress merely took the trouble to include detailed "findings" in each new statute that specified how the conduct at issue would substantially affect interstate commerce, it would satisfy the standards set out by the narrow federalist majority on the Court. ${ }^{16}$ But the narrow conservative majority on the Court took

\footnotetext{
13514 U.S. 549 (1995).

${ }^{14}$ Id. at 561-62.

${ }^{15} 514$ U.S. at $615-31$.

${ }^{16}$ I cheerfully made these arguments myself in Rena I. Steinzor, Unfunded Mandates and the "New (New) Federalism”: Devolution, Revolution, or Reform?, 81 MiNN. L. REV. 97, 154-65 (1996).
} 
Beyond Environmental Law: Policy Proposals for a Better Environmental Future, Alyson Flournoy and David Driesen, eds. (Cambridge University Press, forthcoming 2010)

Chapter: The Constitution and Our Debt to the Future

April 11, 2009

Copyright 2009 by Rena Steinzor--Please do not cite, quote, or copy without express permission of author.

another swipe at the problem five years later in Morrison v. United States, striking down a statute that gave battered women the right to bring tort suits in the federal courts. ${ }^{17}$ This time, Congress had minded its manners, making extensive findings regarding the adverse impact of gendermotivated violence on interstate commerce. Justices Rehnquist, Scalia, Thomas, Kennedy, and O’Connor were not satisfied, holding that the Constitution imposes real limits on Congress' Commerce Clause authority when "non-economic" activities such as assault are involved. ${ }^{18}$ This conclusion demonstrates a serious intention to curb expansive federal regulation of purely intrastate activities. As Professor Robert Percival has written:

Morrison thus raises the prospect that Congress cannot constitutionally regulate intrastate activity that the Court deems noneconomic in character. This could mean that Congress lacks the power to prohibit endangered species from being killed by activity that is not characterized as economic in nature, such as recreational dirt-biking. ${ }^{19}$

Dicta in Solid Waste Agency of Northern Cook County v. United States Army Corps of Engineers (SWANNC) $)^{20}$ underscore these fears. Petitioners, a consortium of municipalities, argued that they did not need to obtain a permit to fill wetlands located in an abandoned sand and gravel pit because these sensitive areas were isolated from hydrological systems that crossed state lines. Respondents, the Army Corps of Engineers, argued that the wetlands were habitat for migratory birds that were pursued across state lines by millions of hunters and bird watchers annually, establishing the required nexus with interstate economic activity under the Commerce Clause. The Supreme Court majority (Rehnquist, O’Connor, Scalia, Kennedy, and Thomas) expressed skepticism about the claim that people were pursuing the birds across state lines, but

\footnotetext{
17529 U.S. 598, 700-701 (2000).

${ }^{18}$ Id. at 613.

19 Percival, supra note 10 , at 837.

20531 U.S. 159 (2001). The Fourth Circuit has gone as far as to declare that Commerce Clause authority does not extend to isolated wetlands. United States v. Wilson, 133 F.3d 251 (4 ${ }^{\text {th }}$ Cir. 1997).
} 
Beyond Environmental Law: Policy Proposals for a Better Environmental Future, Alyson Flournoy and David Driesen, eds. (Cambridge University Press, forthcoming 2010)

Chapter: The Constitution and Our Debt to the Future

April 11, 2009

Copyright 2009 by Rena Steinzor--Please do not cite, quote, or copy without express permission of author.

decided to avoid extending its constitutional precedents. Instead, they decided the case on the grounds that the Clean Water Act itself excluded so-called "isolated” wetlands from its jurisdiction—a concept that imagines boggy land where no boat can travel as removed from other hydrological systems that cross state lines, despite extensive evidence that connections beneath the land's surface are much more extensive than the casual observer imagines. ${ }^{21}$ The possibility that the migratory birds could land on these patches of land was not sufficient to demonstrate that the bogs came within the statute's jurisdiction.

Despite this reliance on statutory interpretation, the majority could not resist taking a swipe at expansive readings of the Commerce Clause: "Where an administrative interpretation of a statute invokes the outer limits of Congress' power, we expect a clear indication that Congress intended that result..”22 The dissent (Stevens, Souter, Ginsberg, and Breyer) disagreed, first on statutory and then on constitutional grounds: "The power to regulate commerce among the several States necessarily and properly includes the power to preserve the natural resources that generate such commerce." ${ }^{23}$ Environmentalists widely perceived the case and its close successor, Rapanos v. U.S., as disasters that gutted Clean Water Act wetlands protections because it pinned the Army Corps and other federal officials down in lengthy deliberations of whether wetlands were "isolated" or not. ${ }^{24}$ The grave constitutional implications of the decision remain unclear, although Congress is considering legislation to broaden the Corps' jurisdiction. ${ }^{25}$

\footnotetext{
21 Id. at $171-72$.

22 Id. at 172.

23 Id. at 196.

24547 U.S. 715 (2006).

25 Linda Roeder, Clean Water Act: Jurisdiction Over Wetlands, Infrastructure, Stormwater Runoff Top Agenda This Year, 40 ENVTL. REP. 24 (2009).
} 
Beyond Environmental Law: Policy Proposals for a Better Environmental Future, Alyson Flournoy and David Driesen, eds. (Cambridge University Press, forthcoming 2010)

Chapter: The Constitution and Our Debt to the Future

April 11, 2009

Copyright 2009 by Rena Steinzor--Please do not cite, quote, or copy without express permission of author.

The outcome of the 2008 presidential election suggests that the conservative Supreme Court justices who have led these assaults on Commerce Clause jurisprudence are unlikely to muster a majority for further campaigns. Without the votes, their enthusiasm for the arduous work of re-aligning the large body of Commerce Clause precedent to include only demonstrably economic effects is likely to fade. As Justice Souter's dissent in Morrison noted, any effort by the Court to craft clear rules distinguishing economic from noneconomic behavior, much less behavior that has ramifications intrastate from behavior that has ramifications interstate, is fraught with peril. ${ }^{26}$ Justice Souter reminded his colleagues of the Court's misadventure in National League of Cities v. Usery, where another narrow majority attempted to distinguish between "traditional state functions" and instances where states behaved more like commercial actors, spawning 300 incoherent decisions by the lower federal courts. ${ }^{27}$ The chaos so alarmed Justice Blackmun that he switched his vote only nine years later, holding with a similarly narrow majority in Garcia v. San Antonio Metropolitan Transit Authority that Congress was well within its Commerce Clause authority when it regulated the labor conditions of state and local workers. ${ }^{28}$

The likelihood that the Supreme Court will pass on an opportunity to advance the Morrison holding should deter the lower federal courts from pursuing such campaigns, although the significant cadre of conservative judges on appellate panels could decide to raise the issue in an appropriate case regardless of their chances to persuade a majority of Supreme Court justices to follow suit. Such strange things have happened. Consider, for example, the D.C. Circuit's

\footnotetext{
26529 U.S. at 700-701 (2000)

27426 U.S. 833 (1976).

28469 U.S. 528 (1985).
} 
Beyond Environmental Law: Policy Proposals for a Better Environmental Future, Alyson Flournoy and David Driesen, eds. (Cambridge University Press, forthcoming 2010)

Chapter: The Constitution and Our Debt to the Future

April 11, 2009

Copyright 2009 by Rena Steinzor--Please do not cite, quote, or copy without express permission of author.

effort to invoke the "non-delegation doctrine” to slap down the Environmental Protection Agency’s (EPA) efforts to tighten regulation under the Clean Air Act. ${ }^{29}$ That doctrine had lain dormant for decades until a group of enterprising conservative Supreme Court practitioners decided to revive it in something of a "hail Mary" pass before a very conservative panel. The panel's decision to take them up on this suggestion left the impression that it was daring the Supreme Court to take a huge step to the right rather than crafting a workmanlike precedent. Ultimately, the Court dismissed the challenge out of hand, voting 8-0 to uphold the EPA regulations. $^{30}$

Were conservative judges to go on a hunt for constitutional reasons to reverse either NELA or climate change legislation as exceeding Congress' Commerce Clause authority, they would probably argue that the portions of the legislation that seek to protect a legacy for future generations lack any rational basis under the Commerce Clause because the intended beneficiaries—natural resources and lives not yet extant—have no current "economic" or market-based value in the context of interstate commerce. No one alive today can engage in transactions-commercial or noncommercial--with beings not yet in existence. Congress therefore lacks any authority to burden the present with this imaginary debt to the future. This logic, however, would compel the courts to lift their black robs high in order to take the leap from the frying pan into the fire. Parsing the temporal dimensions of federal statutes in order to ensure that it only benefits people alive today, and then only in an economic way, are exercises that make earlier debates look like child's play.

\section{B. Property Clause}

29 Am. Trucking Ass'ns v. U.S. EPA, 175 F. 3d 1027 (1999).

30 Whitman v. Am. Trucking Ass'ns, 531 U.S. 457 (2001). 
Beyond Environmental Law: Policy Proposals for a Better Environmental Future, Alyson Flournoy and David Driesen, eds. (Cambridge University Press, forthcoming 2010)

Chapter: The Constitution and Our Debt to the Future

April 11, 2009

Copyright 2009 by Rena Steinzor--Please do not cite, quote, or copy without express permission of author.

The Constitution grants Congress explicit authority to control what happens on federal lands stating, in Article IV, Section 3 that it "shall have Power to dispose of and make all needful Rules and Regulations respecting the Territory or other Property belonging to the United States; and nothing in this Constitution shall be so construed as to Prejudice any Claims of the United States, or of any particular State.” 31 To the extent that NELA required managers in the Executive Branch to conserve natural resources owned by the federal government, this clause would be the beginning and end of any debate over the proposal's constitutionality. But guaranteeing the sustainable use of federally owned natural resources would require two crucial, additional steps: (1) terminating or placing conditions on mineral leases, grazing permits, or similar extraction agreements that allow private parties to exploit such resources ${ }^{32}$ and (2) controlling the use of non-federal land if the activity would make achievement of NELA's mandates impossible. The complex issues involved in curtailing or revoking federal leases are beyond the scope of this chapter. In the second set of circumstances, a broader search for constitutional authority would be necessary.

\section{Cost-Benefit Analysis}

\section{The "Spend-down Ethic"}

Most practicing lawyers are content to leave debates over constitutional interpretation to the academy; they pick up on the law as it comes out of courts or legislatures, rarely examining its constitutional roots. Legislators likewise spend little time second guessing their assumptions of constitutional authority, except when presented with the argument that they are abridging

31 U.S. CONST., art. IV, §3.

32 See, e.g., Pa. Coal Co. v. Mahon, 260 U.S. 393 (1922) (invalidating the federal Kohler Act on due process grounds for allowing the government to take private mineral rights without just compensation). 
Beyond Environmental Law: Policy Proposals for a Better Environmental Future, Alyson Flournoy and David Driesen, eds. (Cambridge University Press, forthcoming 2010)

Chapter: The Constitution and Our Debt to the Future

April 11, 2009

Copyright 2009 by Rena Steinzor--Please do not cite, quote, or copy without express permission of author.

individual rights. The body politic debates guns, abortion, the First Amendment, and the occasional search and seizure. On such relatively rare occasions, legislators chide their colleagues with the prediction that a proposal will fail constitutional muster. But the core rationale for any law—-the affirmative reasons why it represents an appropriate exercise of legislative authority under the Constitution—are seldom mentioned on the House or Senate floor. Despite this dearth of explicit references, the way the Constitution frames a problem has profound effects on the way legislation and its implementation are perceived. Questions about the appropriate dimensions of congressional authority under the Commerce Clause may reach the public in deep disguise, but clearly involve disputes over which level of government should control the marketplace and the expenditure of money. Should the federal government be able to impose "unfunded mandates" on state and local governments? Is it acceptable for a town to bar the disposal of out-of-state waste at the local landfill? Which level of government was at fault for the damage caused by Hurricanes Katrina and Rita, and which officials should plan and pay for recovery? Even Katrina—a natural disaster of unparalleled proportions that most closely resembled war in its consequences for the civilian population-required a federal response not because of any officially articulated constitutional obligation to save lives or provide succor to devastated communities but rather because the national government has the authority to limit the effects of events that shake the foundations of commerce.

From this broader perspective, we can discern Commerce Clause ideas as the fault lines that dog any environmental dispute. Reliance on the federal authority to promote marketplace vigor sets the stage for the supposed trade-off between jobs and the environment and between public health and prosperity. Democrats insist that we can find better ways to protect the 
Beyond Environmental Law: Policy Proposals for a Better Environmental Future, Alyson Flournoy and David Driesen, eds. (Cambridge University Press, forthcoming 2010)

Chapter: The Constitution and Our Debt to the Future

April 11, 2009

Copyright 2009 by Rena Steinzor--Please do not cite, quote, or copy without express permission of author.

environment, therefore sacrificing less economic growth. ${ }^{33}$ Republicans claim that environmental regulations waste money, stifle small business, and cripple the nation’s competitiveness. ${ }^{34}$ The common ground for both arguments is the view that environmental protection and the economy are in a relationship that demands their trade-off against one another. If the constitutional authority for environmental regulation rests on protecting commerce and markets, then weighing costs against monetized benefits appears to be both logical and inevitable.

To gauge the importance of these assumptions, consider for a moment the arguments that would be made by people who oppose the idea of codifying an obligation to conserve resources for future generations. The proposition that we owe resources, much less specific amounts of money, to future generations, is likely to prove exceptionally controversial. In fact, opponents will argue, when we enhance monetary wealth by consuming resources, we provide the economic resources needed by future generations to buy their way out of any irreversible environmental trouble. Or, to phrase the argument another way, resources in and of themselves have no value until they are bought and sold. Refraining from buying and selling them has absolutely nothing to do with encouraging the promotion of commerce, which the national government has always done by stabilizing markets, not by enforcing fanciful prohibitions against market transactions.

33 U.S. EPA, Summary RePort to the President: The Presidential Regulatory ReForm Initiative By the EnVironmental PRotection AgEnCy, reprinted in 1995 DAily EnV'T. REP. (BNA) 121 (June 23, 1995) ("We have learned that by focusing on results, not on how results are achieved, we can tap the creativity of Americans to devise cleaner, cheaper, smarter ways of protecting the environment.")

${ }^{34}$ For an admittedly extreme, but not a-typical, example, consider Congress Tom DeLay's comparison of the EPA to the Gestapo. Bruce Burkhard, "Year in Review Congress vs. Environment: Environmental Laws Suffer under GOP-Controlled Congress,” Cable News Network, Dec. 29, 1995, http://www.cnn.com/EARTH/9512/congress_enviro/. An audio recording of Congressman DeLay’s comments is available through the online version of the article. 
Beyond Environmental Law: Policy Proposals for a Better Environmental Future, Alyson Flournoy and David Driesen, eds. (Cambridge University Press, forthcoming 2010)

Chapter: The Constitution and Our Debt to the Future

April 11, 2009

Copyright 2009 by Rena Steinzor--Please do not cite, quote, or copy without express permission of author.

Professor Flournoy refers to these arguments as the "spend-down ethic,” explaining that they implicitly reject any moral or ethical commitment to preserve resources for future generations. Instead, this ethic posits that ownership of resources and control over how rapidly they are consumed are the sole prerogative of those now living on the planet. ${ }^{35}$ Under Professor Flournoy's analysis, unless we take decisive action to fundamentally modify our patterns of consumption, the spend-down ethic will win the day. And it is very hard to articulate an economic reason for making ourselves so uncomfortable.

\section{Cost-Benefit Analysis and Discounting}

The application of cost/benefit analysis to environmental decisions became mandatory during the administration of Ronald Reagan, carried through the presidency of George H.W. Bush, two terms of the Clinton Administration, and two terms of the George W. Bush Administration. ${ }^{36}$ President Obama has appointed Harvard Professor Cass Sunstein as director of the Office of Management and Budget's (OMB) Office of Information and Regulatory Affairs (OIRA), the unit charged with enforcing this methodology throughout the government, and he is expected to continue the practice. To be sure, the four administrations applied cost-benefit analysis with significantly different levels of stringency. But as the methodology took hold, and its practitioners became more sophisticated, it loomed as the central hurdle regulatory proposals had to traverse.

35 INSERT REFERENCE TO FLOURNOY CHAPTER.

36 President Reagan issued Executive Order 12291 in 1981. Executive Order no. 12,291, Federal Register 46 (February 17, 1981): 13193, http://www.archives.gov/federal-register/codification/executive-order/12291.html. Executive Order 12866, which replaced 12291, was first issued under President Clinton, and was continued by President Bush without amendment until January 18, 2007, when it was supplemented by Executive Order 13422. Executive Order no. 12,866, Federal Register 58 (Oct. 4, 1993): 51735, http://www.whitehouse.gov/omb/ inforeg/eo12866.pdf; Executive Order no. 13422, Federal Register 72 (Jan. 23, 2007), http://www.whitehouse.gov/news/releases/2007/01/20070118.htm. 
Beyond Environmental Law: Policy Proposals for a Better Environmental Future, Alyson Flournoy and David Driesen, eds. (Cambridge University Press, forthcoming 2010)

Chapter: The Constitution and Our Debt to the Future

April 11, 2009

Copyright 2009 by Rena Steinzor--Please do not cite, quote, or copy without express permission of author.

Under cost-benefit analysis, economists place a monetary value on—or "monetize" — the anticipated compliance costs of firms that must comply with a regulation. They also monetize "lost opportunity costs," or the money businesses will lose if they cannot invest those compliance costs. The total of these sums is compared to the monetary value of the benefits that the regulation would produce. So, for example, economists estimate that the monetary value of a single life saved is between $\$ 2.5$ and 6.8 million. ${ }^{37}$ The gist if these calculations, then, is to make the trade-offs at stake in any regulatory decision— to protect or not to protect? how stringently to protect?-resemble a commercial transaction.

Strong deterrents against the full consideration of harm to future generations are embedded as irrefutable elements in the daily practice of cost-benefit analysis, chiefly because also economists insist on "discounting" the value of injury avoided. They reason that many regulations do not save lives immediately. I may die in a car crash tomorrow that would have been prevented by a safety rule, but if I am exposed to a chemical compound and get cancer, I will not die for 30 years. In calculating the benefits of saving my life in 30 years, then, we should figure out how much money we would have to invest today to come up with the going rate for a life saved in 30 years. The OMB recommends that agencies use discount rates of three to seven percent to define a range for their discounted benefit calculations. ${ }^{38}$ Obviously,

\footnotetext{
${ }^{37}$ ThOMAs O. McGarity \& Sidney A. Shapiro, Workers AT Risk: The FAILED Promised of THE OCCUPATIONAL SAFETY AND HEALTH ADMINISTRATION 271 (1993).

38 The OMB justified discounting in its guidance on how to conduct cost/benefit analysis for all federal agencies U.S. OMB, Circular A-4 at 31-37 (September 17, 2003) [hereinafter Circular A-4], available at http://www.whitehouse.gov/omb/ circulars/a004/a-4.pdf. For a critical explanation, see Lisa Heinzerling, Discounting Our Future, 34 LAND \& WATER L. REV. 39 (1999). For a justification of using discounting to quantify long-term benefits, albeit at a significantly lower rate than is commonly used by the federal government, see Daniel A. Farber \& Paul A. Hemmersbaugh, The Shadow of the Future: Discount Rates, Later Generations, and the Environment, 46 VANDERBILT L. REV. 267 (1993).
} 
Beyond Environmental Law: Policy Proposals for a Better Environmental Future, Alyson Flournoy and David Driesen, eds. (Cambridge University Press, forthcoming 2010)

Chapter: The Constitution and Our Debt to the Future

April 11, 2009

Copyright 2009 by Rena Steinzor--Please do not cite, quote, or copy without express permission of author.

discounting results in substantially decreasing the benefits of a rule that prevents such "long latency” injury. I must invest a much smaller sum today to come up with a much bigger sum at the end of 30 years. If the benefits are stretched out to 50 or 100 years, and cover lives saved of people who are not year alive, the investments required today dwindle to insignificance.

Discounting, to put it mildly, is a major hurdle for any effort to justify regulations under the National Environmental Legacy Act in cost/benefit terms.

OMB economists are untroubled by these outcomes, although they acknowledge that such situations raise "special ethical considerations." ${ }^{39}$ After all, "[f]uture citizens who are affected by such choices cannot take part in making them, and today's society must act with some consideration of their interests. ${ }^{40}$ Nevertheless, the economists argue that discounting should remain an integral part of cost-benefit analysis because future generations will be wealthier than we are today. Using a lower discount rate or otherwise giving future generations an economic advantage would therefore take money away from poorer people today to benefit people who will be richer tomorrow.

All of these problems with cost-benefit analysis are compounded by the fact that efforts to quantify the value of natural resources, from the grizzly bear to the polar ice caps, are rudimentary at best. ${ }^{41}$ Problems of causation are fierce. Is an adequate supply of potable water in the Seattle metropolitan area worth enough (discounted) money to our grandchildren's children to justify our investment in sustainable wetlands management in Mount Baker-

39 Circular A-4, supra note 38, at 35-6.

${ }^{40}$ Id.

${ }^{41}$ See, e.g., the National Capital Project, a cooperative venture of The Nature Conservancy, the World Wildlife Fund and the Woods Institute for the Environment at Stanford University, summarized at http://www.naturalcapitalproject.org/california_prim.html. The Project began in 2006 with the goal of determining "what is nature worth to people?” It has made limited progress. 
Beyond Environmental Law: Policy Proposals for a Better Environmental Future, Alyson Flournoy and David Driesen, eds. (Cambridge University Press, forthcoming 2010)

Chapter: The Constitution and Our Debt to the Future

April 11, 2009

Copyright 2009 by Rena Steinzor--Please do not cite, quote, or copy without express permission of author.

Snoqualmie National Forest? The link between managing wetlands and producing potable water is already a scientifically complex question. Quantifying the value of each in a decades-long timeframe is guesswork at best.

Proponents of cost-benefit analysis might well reply that we must simply bite the bullet and assume the burden of gathering such information. How else should we determine whether we should spend lots of money today when future generations may well be able to afford to work their way around the dearth of natural resources?

The ultimate answer to this apparently reasonable question is that the most scrutinized, vetted, peer reviewed, and expensive body of scientific evidence ever gathered by the human race proves that unless we take swift action to change our conduct--and perhaps even if we do-we will destroy essential natural resources to the point that they will never be available to our children's children, much less our grandchildren's grandchildren. No matter how much money future generations may have, crucial resources will not be on the market because they will not exist.

\section{The Irreversible Effects of Climate Change}

The Intergovernmental Panel on Climate Change (IPCC) is the most exceptional organization of scientific expertise in history. Founded in 1988 by two U.N.-sponsored organizations, the World Meteorological Organization and the Environment Programme, it now includes over 3,000 scientists worldwide who study every conceivable aspect of climate change, from meteorology to geology to hydrology to anthropology. The IPCC does not conduct scientific research, but instead reviews, synthesizes, and interprets existing and emerging research, much of which is being conducted by its individual members. The IPCC is divided into 
Beyond Environmental Law: Policy Proposals for a Better Environmental Future, Alyson Flournoy and David Driesen, eds. (Cambridge University Press, forthcoming 2010)

Chapter: The Constitution and Our Debt to the Future

April 11, 2009

Copyright 2009 by Rena Steinzor--Please do not cite, quote, or copy without express permission of author.

four working groups and operates by consensus, achieving unanimous agreement to the text in its published reports, which are commonly referred to as "assessments.” The assessments are strictly limited to objective statements about the state of science, as opposed to policy issues or conclusions. While some scientists continue to quibble at the margins of the conclusions presented in these voluminous reports, credible alternative research disputing the IPCC's core conclusions--the most fundamental of which is that the use of fossil fuel has triggered potentially catastrophic climate change--simply does not exist.

In 2007, Working Group I, which focuses on the physical science basis for observations and predictions regarding climate change concluded: "Warming of the climate system is unequivocal, as is now evident from observations of increases in global average air and ocean temperatures, widespread melting of snow and ice, and rising global average sea level.”42 The scientists continued, "The globally average surface temperature is projected to increase by 1.4 to $5.8^{\circ} \mathrm{C}$ over the period 1990 to 2100 , with nearly all land areas warming more rapidly than the global average."43 As a result, "It is very likely that hot extremes [and] heat waves...will continue to become more frequent."44

Working Group II, which focuses on impacts, adaptation, and vulnerability, concluded that same year: “Observations since 1961 show that the average temperature of the global ocean

\footnotetext{
42 Richard B. Alley et Al., InTERgovernmental PANEL On Climate Change: Summary FOR PolicymaKeRs, Climate Change 2007: The Physical SCIENCE Basis. Contribution OF Working Group I tO THE Fourth Assessment Report of the InTERgovernmental PANEL on Climate Change 5 (Susan Solomon ed., Cambridge University Press 2007) [hereinafter ALLEY], available at http://www.ipcc.ch/pdf/assessment-report/ar4/wg1/ar4wg1-spm.pdf.

43 Robert Watson et al., Intergovernmental Panel On Climate Change: Climate Change And Biodiversity, Intergovernmental Panel on Climate Change TeChnical Paper V 10 (Habiba Gitay ed., 2002) [hereinafter WATSON]. available at http://www.ipcc.ch/pdf/technicalpapers/climate-changes-biodiversityen.pdf.

${ }^{44}$ AlLEY, supra note 42, at 15.
} 
Beyond Environmental Law: Policy Proposals for a Better Environmental Future, Alyson Flournoy and David Driesen, eds. (Cambridge University Press, forthcoming 2010)

Chapter: The Constitution and Our Debt to the Future

April 11, 2009

Copyright 2009 by Rena Steinzor--Please do not cite, quote, or copy without express permission of author.

has increased to depth of at least $3000 \mathrm{~m}$ and that the ocean has been absorbing more than $80 \%$ of the heat added to the climate system. Such warming causes seawater to expand, contributing to sea level rise. ${ }^{45}$ As a result, "Many millions more people are projected to be flooded every year due to sea-level rise by the 2080s. Those densely-populated and low-lying areas where adaptive capacity is relatively low, and which already face other challenges such as tropical storms or local coastal subsidence, are especially at risk." ${ }^{46}$

Climate change will have a severe effect on the diversity and survival of a wide range of species: “Approximately 20-30\% of plant and animal species assessed so far are likely to be at increased risk of extinction if increases in global average temperature exceed $1.5-2.5^{\circ} \mathrm{C}$ [medium confidence]." ${ }^{47}$ The IPCC continued, "While there is little evidence to suggest that climate change will slow species losses, there is evidence that it may increase species losses... Many of the Earth's species are already at risk of extinction due to pressures arising from natural processes and human activities. Climate change will add to these pressures especially for those with limited climatic ranges and/or restricted habitat requirements." ${ }^{\text {48 }}$

A comprehensive recitation of these disturbing projections is well beyond the scope of this chapter. Suffice it to say that this indisputable science should cast grave doubt on the wisdom of micro-cost/benefit analyses of specific actions that are conducted on the premise that future generations will be able to buy their way out of trouble. Not only does discounting at the

\footnotetext{
${ }^{45}$ Id.at 5.

${ }^{46}$ Neil Adger et Al., Intergovernmental Panel on Climate Change: Summary for Policymakers, CLIMATE CHANGE 2007: IMPACTS, ADAPTATION AND VULNERABILITY. CONTRIBUTION OF WORKING GROUP II TO the Fourth Assessment Report of the Intergovernmental Panel on Climate Change 12 (Martin Parry ed., Cambridge University Press 2007) [hereinafter ADGER], available at available at http://www.ipcc.ch/pdf/assessmentreport/ar4/wg2/ar4-wg2-spm.pdf.

${ }^{47}$ Id. at 11.

${ }^{48}$ WATSON, supra note 43, at 16.
} 
Beyond Environmental Law: Policy Proposals for a Better Environmental Future, Alyson Flournoy and David Driesen, eds. (Cambridge University Press, forthcoming 2010)

Chapter: The Constitution and Our Debt to the Future

April 11, 2009

Copyright 2009 by Rena Steinzor--Please do not cite, quote, or copy without express permission of author.

micro-level appear myopic, the sum total of its results is likely to lead us to the same place that scientists have been warning against with increasing urgency: inaction in all but the most grotesquely imbalanced circumstances when the greed of present generations will wipe out the survivability of future generations on a grand scale. In the big picture, aggregating all of our natural resource use, we are already there. By fracturing this larger picture into millions of small shards, we justify business as usual, which we can ill afford.

\section{Cultural Values}

Of course, putting the Commerce Clause to one side for a moment, it should be obvious that many Americans harbor the value that we must protect future generations or, conversely, that we owe it to our children and their children not to pass on a planet in peril. The most articulate statements of these values arise from the religious community. In 2004, the National Association of Evangelicals adopted a groundbreaking statement entitled "For the Health of the Nation," which declared seven principles that should guide the participation of its members in the formulation of public policy. The Association is the largest evangelical organization in the country, with over 45,000 churches, 60 evangelical denominations, and 30 million members. Under the heading “We Labor to Protect God's Creation,” the drafters state:

We affirm that God-given dominion is a sacred responsibility to steward the earth and not a license to abuse the creation of which we are a part... This implies the principle of sustainability... Because clean air, pure water, and adequate resources are crucial to public health and civic order, government has an obligation to protect its citizens from the effects of environmental degradation. This involves the urgent need to relieve human suffering caused by bad environmental practice. . . We encourage Christians to shape their personal lives in creation-friendly ways: practicing effective recycling, conserving resources, and experiencing the joy of contact with nature. We urge government to 
Beyond Environmental Law: Policy Proposals for a Better Environmental Future, Alyson Flournoy and David Driesen, eds. (Cambridge University Press, forthcoming 2010)

Chapter: The Constitution and Our Debt to the Future

April 11, 2009

Copyright 2009 by Rena Steinzor--Please do not cite, quote, or copy without express permission of author.

encourage fuel efficiency, reduce pollution, encourage sustainable use of natural resources, and provide for the proper care of wildlife and their natural habitats. ${ }^{49}$

This passionate commitment has come to be called "creation care."

The Constitution, as amended by the Bill of Rights, and its companion document, the Declaration of Independence, embody ethical values that are at the core of Aerican culture. These values extend far beyond the ministerial, albeit important, responsibility to preserve commerce between the states. Yet the Commerce Clause is invoked-- tacitly by the body politic and explicitly by the courts - to justify the vast range of federal interventions in American life, from social welfare programs to the environment to the protection of public health. Should we turn our backs on these inconsistencies, or is there another constitutional foundation for a more ethical middle ground?

\section{Part III: Safeguarding the General Welfare}

We the People of the United States, in Order to form a more perfect Union, establish Justice, insure domestic Tranquility, provide for the common defence, promote the general Welfare, and secure the Blessings of Liberty for ourselves and our Posterity, do establish this Constitution for the United States of America. ${ }^{50}$

The Congress shall have power to lay and collect taxes, duties, imposts and excises, to pay the debts and provide for the common defense and general welfare of the United States; but all duties, imposts and excises shall be uniform throughout the United States. ${ }^{51}$

\section{A. The States' Police Power}

The argument that the federal government's efforts to deal with long-term threats to public health and the environment should be lifted from the constraints of the Commerce Clause

\footnotetext{
${ }^{49}$ David P. Gushee, The Future of Faith in American Politics: The Public Witness of the Evangelical CENTER 233-4 (Waco, Texas: Baylor University Press, 2008).

${ }^{50}$ U.S. CONST., Preamble.

${ }^{51}$ U.S. ConsT., art. I, §1.
} 
Beyond Environmental Law: Policy Proposals for a Better Environmental Future, Alyson Flournoy and David Driesen, eds. (Cambridge University Press, forthcoming 2010)

Chapter: The Constitution and Our Debt to the Future

April 11, 2009

Copyright 2009 by Rena Steinzor--Please do not cite, quote, or copy without express permission of author.

and placed under the umbrella of the national government's efforts to promote the "general welfare" is best supported by the Supreme Court's confirmation of the states' "police power" to combat comparable threats. At the time of the American Revolution, this concept was captured in the Latin phrase "salus populi supreme lex est," or "the safety of the people is the supreme law.” States have a long and noble history of regulating practices that could threaten public health, beginning as early as the 1700s when smallpox inoculations were common in the New England colonies, extending through the sanitarian movement in America's major cities during the late $19^{\text {th }}$ and early $20^{\text {th }}$ centuries, covering the campaign to eradicate polio during the 1950 s, up until the present day when the threat of AIDs has challenged their capacity to the breaking point. $^{52}$

The Slaughter-House cases decided by the Supreme Court in 1872 typify this jurisprudence. ${ }^{53}$ At issue was a Louisiana law granting a monopoly to a single slaughterhouse on the grounds that it would be easier to control the practices that led such places to spread disease through the careless disposal of animal carcasses and other wastes. The Court treated the case as a showdown between state police power prerogatives and the recently enacted $14^{\text {th }}$ Amendment grant of "privileges and immunities" to citizens of the United States-in this instance, the chosen slaughterhouse's competitors and their privilege to continue in business. ${ }^{54}$ Owners of competing slaughterhouses challenged the law, alleging that their “privileges and immunities” were violated

\footnotetext{
${ }^{52}$ For a compelling explanation of the history of public health law, see Wendy E. Parmet, From Slaughter-House to Lochner: The Rise and Fall of the Constitutionalization of Public Health, 40 AM. J. LEgAL HISTORY. 476 (1996) [hereinafter Rise and Fall] (focusing on the full sweep of historical developments from colonial times, thorough the New Deal, to the present) and Wendy E. Parmet, Health Care and the Constitution: Public Health and the Role of the State in the Framing Era, 20 HASTINGS CONST. L. Q. 267 (1992-1993) [hereinafter Health Care and the Constitution] (considering especially the Framers' expectations about the role of the government with respect to public health during colonial times).

5383 U.S. 36 (1872).

${ }^{54}$ U.S. CONST., amend. XIV.
} 
Beyond Environmental Law: Policy Proposals for a Better Environmental Future, Alyson Flournoy and David Driesen, eds. (Cambridge University Press, forthcoming 2010)

Chapter: The Constitution and Our Debt to the Future

April 11, 2009

Copyright 2009 by Rena Steinzor--Please do not cite, quote, or copy without express permission of author.

by the state’s grant of a monopoly to a competitor. In response, the Supreme Court cited the "power here exercised by the [Louisiana] legislature,” which "in its essential nature” has always belonged to the states." ${ }^{, 55}$ The Court continued:

This is called the police power: and it is declared by Chief Justice Shaw that it is much easier to perceive and realize the existence and sources of it than to mark its boundaries, or prescribe limits to its exercise. ... Upon it depends the security of the social order, the life and health of the citizen, the comfort of an existence in a thickly populated community, the enjoyment of private and social life, and the beneficial use of property. ${ }^{56}$

The Slaughter-House cases established the premise that the states are presumed to have broad police powers and that the question for the federal courts is whether they had gone too far in exercising it. But the strength of this holding weakened over time both because the state law at issue came to be viewed as a cynical exercise in post-Reconstruction patronage and because the threat of epidemics and other urgent public health emergencies waned.

Once the urgency and barely contained terror of cholera and similar diseases was brought under control by better sanitation and medical breakthroughs such as vaccination, state public health officers turned to what Professor Wendy Parmet calls "endemic" threats to public health, such as working conditions and occupational exposure to harmful substances. ${ }^{57}$ The federal courts balked, largely because these new targets provoked state efforts to control industrial practices, considered anathema from the late 1800's to the New Deal. The low point in this jurisprudence was the Supreme Court's 1905 decision in Lochner v. New York ${ }^{58}$ overturning the state of New York's efforts to control the hours that bakers were allowed to work. Despite the dissent's citation of ample evidence demonstrating the severe harm to bakery workers caused by

55 Id. at 61.

56 Id. at 61.

57 See Rise and Fall, supra, note 52, at 493-501.

58198 U.S. 45 (1905). 
Beyond Environmental Law: Policy Proposals for a Better Environmental Future, Alyson Flournoy and David Driesen, eds. (Cambridge University Press, forthcoming 2010)

Chapter: The Constitution and Our Debt to the Future

April 11, 2009

Copyright 2009 by Rena Steinzor--Please do not cite, quote, or copy without express permission of author.

exposure to flour dust, intense heat, and long hours of work in a standing position, ${ }^{59}$ the Court refused to even recognize the state law as an exercise of police power, instead dismissing it as a "labor law" that interfered with the constitutional right of freedom to contract. ${ }^{60}$

As the New Deal era unfolded, World War II was fought and won, and America settled into the post-industrialization era, the Supreme Court repudiated Lochner in a series of decisions. But these cases stopped mentioning the police power and were instead rationalized as federal deference to the states' prerogatives. For example, West Coast Hotel Co. v. Parrish ${ }^{61}$ upheld a Washington statute requiring that women be paid a minimum wage, holding that

[i]n dealing with the relation of employer and employed, the Legislature has necessarily a wide field of discretion in order that there may be suitable protection of health and safety, and that peace and good order may be promoted through regulations designed to insure wholesome conditions of work and freedom from oppression. ${ }^{62}$

Similarly, in Day-Brite Lighting v. State of Missouri, the Court upheld a Missouri statute allowing workers to be absent from their places of employments for four hours between the opening and closing of election polls:

Our recent decisions make plain that we do not sit as a super-legislature to weigh the wisdom of legislation nor to decide whether the policy which it expresses offends the public welfare. ... [T] he state legislatures have constitutional authority to experiment with new techniques; they are entitled to their own standard of the public welfare; they may within extremely broad limits control practices in the business-labor field, so long as specific constitutional prohibitions are not violated and so long as conflicts with valid and controlling federal laws are avoided. ${ }^{63}$

In a series of articles notable as much for their careful study of history as their insightful constitutional analysis, Professor Parmet argues that this reluctance to expand the concept of a

\footnotetext{
59198 U.S. at 70-71.

60198 U.S. at 57.

61300 U.S. 379 (1937).

62300 U.S. 379, 392 (1936).

63342 U.S. 421, 423 (1952).
} 
Beyond Environmental Law: Policy Proposals for a Better Environmental Future, Alyson Flournoy and David Driesen, eds. (Cambridge University Press, forthcoming 2010)

Chapter: The Constitution and Our Debt to the Future

April 11, 2009

Copyright 2009 by Rena Steinzor--Please do not cite, quote, or copy without express permission of author.

police power to include widespread and chronic threats to public health, especially where workers were involved, served to “deconstitutionalize” public health law. The phrase "salus populi supreme lex" was dropped from judicial lexicon, and the Supreme Court "abandoned the quest for the boundaries between the public and private spheres of authority." ${ }^{\text {,4 }}$ No one lamented this subtle shift at the time, in large measure because state and federal legislatures were given ample running room by the courts to enact all manner of public health programs, from wage and hour laws to occupational safety laws to environmental regulations.

Professor Parmet concludes that while it may be difficult to document the tangible effects of deconstitutionalization, the cumulative effect of these decisions is to take the focus off government's legitimate and affirmative responsibility to preserve civil society by protecting public health. The states' decisions to spend a great deal of money and control large swaths of industrial activity are rationalized instead on the basis that they are supported by the majority of the voters and should be scrutinized by the courts only where institutional rights are clearly jeopardized or newly energized principles of federalism are compromised. This commentary could as easily be applied to environmental law. Anchoring the constitutionality of environmental statutes on the Commerce Clause also serves to deflect consideration of what government should be expected to do for the people in an affirmative sense. As in the public health context, judicial and legislative debates over the wisdom of environmental policy revolve around the merits and downsides of the individual policy in financial terms — will it cost us too much to clean up the air? — rather than the principle that communities should expect government to preserve this essential natural resource without which a healthy life is impossible.

\footnotetext{
${ }^{64}$ Rise and Fall, supra note 52, at 502.
} 
Beyond Environmental Law: Policy Proposals for a Better Environmental Future, Alyson Flournoy and David Driesen, eds. (Cambridge University Press, forthcoming 2010)

Chapter: The Constitution and Our Debt to the Future

April 11, 2009

Copyright 2009 by Rena Steinzor--Please do not cite, quote, or copy without express permission of author.

Like every scholar firmly anchored in the implications for her theories of current events, Professor Parmet has noted the shocking implications of the tragedies that began on September 11, 2001 for public health constitutional doctrines. ${ }^{65}$ She suggests that these events should have made clear to every observer that the federal government has a crucial role to play in protecting public health from bio-terrorism and emerging threats like bird flu. In this new and fearful era, all three branches of government have an unavoidable stake in removing the barriers between state and federal responsibilities to protect public health. Similarly, the advent of climate change demands a more flexible interpretation of constitutional intent than the Supreme Court has yet realized.

\section{B. The Federal Police Power}

One of the most bizarre and troubling byproducts of the September 11, 2001 attacks was the mailing of anthrax to the offices of Senator Thomas Daschle (D-ND) and NBC News anchor Tom Brokaw. ${ }^{66}$ The Federal Bureau of Investigation later discovered that this act of terrorism was almost certainly conducted by a mentally ill American who worked as a senior researcher in a military laboratory at Fort Detrick in Frederick, Maryland ${ }^{67}$ Regardless of its perpetrator, foreign or domestic, the incident showcased the extraordinarily high expectations Americans harbor toward the national government's ability to protect people from such threats. Had the anthrax spread, the federal government would have organized a coordinated response. Federal officials would depend heavily on local hospitals, police departments, and emergency medical

\footnotetext{
65 Wendy E. Parmet, After September 11: Rethinking Public Health Federalism, J. OF LAW, MEDICINE \& ETHICS, 201-211 (2002).

66 David Johnston \& Alison Mitchell, A Nation Challenged: The Widening Inquiry; Anthrax Mailed to Senate Is Found to Be Potent Form; Case Tied to Illness at NBC, N.Y. TimES at A1 (Oct. 17, 2001).

${ }^{67}$ Scott Shane \& Eric Lichtblau, Scientist's Suicide Linked to Anthrax Inquiry, N.Y. TiMES at A1 (Aug. 2, 2008).
} 
Beyond Environmental Law: Policy Proposals for a Better Environmental Future, Alyson Flournoy and David Driesen, eds. (Cambridge University Press, forthcoming 2010)

Chapter: The Constitution and Our Debt to the Future

April 11, 2009

Copyright 2009 by Rena Steinzor--Please do not cite, quote, or copy without express permission of author.

personnel, but they would be the ones held accountable for curtailing the spread of the dreadful disease. Indeed, most people — especially the federal officials rushing to sit in the hot seat of such crises (former Pennsylvania Governor Tom Ridge, the newly appointed chief of homeland security for then President George W. Bush, dominated the airwaves in the wake of the crisis)— would have considered anyone who questioned this preeminent role unpatriotic.

Despite this clear manifestation of national consensus on the federal government's obligation to exercise what the law has always described as "police powers," we continue to teach law students that only the states have this authority. As the anthrax episode illustrates, the global challenges of the $21^{\text {st }}$ century make this stubborn and constricted reading of the Constitution very much against our national interests. Admittedly, the Supreme Court has never hinted that the police power attributed to the states in its early jurisprudence is the kind of power that should also be attributed to the federal government. On the other hand, it is virtually impossible to imagine any mainstream participant in the national policy debate challenging the proposition that the federal government must play the dominant role in preventing and responding to a global pandemic like bird flu or to international threats like a bio-terrorism attack. And, of course, the federal government has erected an elaborate bureaucratic infrastructure to exercise its police powers (see, e.g., the National Institutes of Health, the Department of Health and Human Services, and the Centers for Disease Control).

In the environmental context, the federal government has long dominated policy making through a system that delegates authority to states that volunteer for the responsibility of implementing federal rules. Among the strongest principles embodied in that system is that federal standards set the floor for minimal protection of public health and the environment but 
Beyond Environmental Law: Policy Proposals for a Better Environmental Future, Alyson Flournoy and David Driesen, eds. (Cambridge University Press, forthcoming 2010)

Chapter: The Constitution and Our Debt to the Future

April 11, 2009

Copyright 2009 by Rena Steinzor--Please do not cite, quote, or copy without express permission of author.

that states can go further if they deem additional protections to be necessary. One statute, the

Clean Air Act, even goes so far as to allow California to regulate motor vehicles to require that

they emit less pollution both because the state has acute air quality problems and because it is

among the largest economies in the world. California must petition to get the EPA's approval of

these more stringent motor vehicle standards, and other states may follow its lead. All of these

provisions mean that states can and have "burdened" interstate commerce with more protective

standards on the rationale that people think of the entire system of law as providing protective

legal tools than as enabling the free flow of economic transactions.

The principle that states can be more protective is not seriously in question. California,

for example, has charged ahead on the regulation motor vehicle emissions for public health

purposes, winning as many as 50 approvals from the EPA to impose more stringent standards.

But this consensus is beginning to unravel in the climate change context, with many large fossil

fuel producers and users demanding preemption of state authority to curb greenhouse gases. ${ }^{68}$

Ironically, the most prominent argument they made is that the federal government has superior

ability to combat this global crisis, which threatens both public health and natural resources. ${ }^{69}$

While I do not agree with the next step of this argument—-that states should be excluded from

governmental efforts to control climate chang ${ }^{70}$--its proponents, which are among the largest

${ }^{68}$ See, e.g., Green Mountain Chrysler Plymouth Dodge Jeep v. Crombie, 508 F.Supp.2d 295, 392 (D.Vt. 2007). In the case, the auto industry argued that California's efforts to pass state laws dealing with this global problem should be preempted by the federal government's exclusive constitutional authority to conduct the nation's foreign affairs.

69 See, e.g., Mass. v. EPA, 549 U.S. 497 (2007) (the Clean Air Act covers greenhouse gas emissions and the EPA must make a decision whether such emissions constitute a sufficient "endangerment" to require regulation under the statute).

${ }^{70}$ See, e.g., Center for Progressive Reform, William Andreen, Robert Glicksman, Nina Mendelson, Rena Steinzor, \& Shana Jones, Cooperative Federalism and Climate Change: Why Federal, State, and Local Governments Must Continue to Partner (2008), available at http://www.progressivereform.org/articles/federalismClimateChange.pdf (visited on March 28, 2009). 
Beyond Environmental Law: Policy Proposals for a Better Environmental Future, Alyson Flournoy and David Driesen, eds. (Cambridge University Press, forthcoming 2010)

Chapter: The Constitution and Our Debt to the Future

April 11, 2009

Copyright 2009 by Rena Steinzor--Please do not cite, quote, or copy without express permission of author.

companies in the world, clearly have acknowledged that much more than the free flow of interstate commerce is at stake. Instead, federal control is viewed as important in ensuring that the United States holds its own in negotiating with the rest of the world over these reductions. Clearly, then, devotion to the Commerce Clause as the source of environmental law is under active reconsideration in the climate change context.

Finally, as daunting as the climate change problem appears to be, other global issues will soon confront the federal government, lending further urgency to the search for a new constitutional framework for the American effort to persuade other countries to diminish their contribution to the global cycles of pollution that threaten the quality of our domestic environment. As just one example, scientists have discovered that much of the particulate pollution that falls in Los Angeles originated in China. ${ }^{71}$

\section{Taxing and Spending}

Pouring the hopes for the future of environmental law into the as-yet unused chalice of the General Welfare Clause is likely to result in overflow, or at the very least a tight fit, unless one specific doctrinal problem is addressed. The Supreme Court held in United States v. Butler that the power to provide for the general welfare is directly tied to congressional taxing and spending authority. ${ }^{72}$ The 1936 case involved agricultural subsidies designed to control crop prices. The Supreme Court struck down the program because it addressed "agricultural

\footnotetext{
${ }^{71}$ Joseph Kahn \& Jim Yardley, As China Roars, Pollution Reaches Deadly Extremes, N.Y. TimEs, Aug. 26, 2007, at A1; see also Jianguo Lin \& Jared Diamond, Revolutionizing China’s Environmental Protection, SCIENCE, Jan. 4, 2008, 37-38; Les Blumenthal, Scientists Fear Impact of Asian Pollutants on U.S., MCClatchy NeWSPAPERS, Aug. 31, 2008.

72 297 U.S. 1 (1936).
} 
Beyond Environmental Law: Policy Proposals for a Better Environmental Future, Alyson Flournoy and David Driesen, eds. (Cambridge University Press, forthcoming 2010)

Chapter: The Constitution and Our Debt to the Future

April 11, 2009

Copyright 2009 by Rena Steinzor--Please do not cite, quote, or copy without express permission of author.

production," a "purely local” industry that only the states were empowered to address. ${ }^{73}$ This aspect of the case is no longer good law given the dramatic expansion of federal Commerce Clause authority discussed earlier. ${ }^{74}$ More significantly, however, the Court also held that the national government's power to provide for the general welfare is conditioned upon its simultaneous exercise of the power to tax to and spend, and this rule remains good law. ${ }^{75}$ Most significantly, the Court stated that the "the power of Congress to authorize expenditures is not limited by the direct grants of legislative power found in the Constitution." ${ }^{\text {76 }}$ Accordingly, if Congress is willing to put its money where its mouth is, whether or not it has the power to legislate under the Commerce Clause, it is free to create programs that promote its perception of what is needed to provide for the general welfare.

The federal government spends considerable sums each year to manage federal lands, deploying park rangers and fire-fighting teams, maintaining the national parks, securing the borders from private sector incursions, building roads, supervising the preservation of wildlife, etc. These substantial financial commitments are probably sufficient to satisfy the Butler test as applied to the core requirements of the National Environmental Legacy Act (NELA), which would mandate the analysis of any major federal action that could affect the long-term sustainability of natural resources located on federally owned lands. However, as discussed at the outset, NELA would also require that action be abandoned or modified if the analysis showed that it would threaten long-term sustainability of federally owned natural resources. The power to block such actions should reasonably extend to actions that take place on privately owned land

\footnotetext{
73297 U.S. at 63-64.

${ }^{74}$ CHEMERINSKY, supra note 5, at 274.

75 Id.

76297 U.S. at 64-65.
} 
Beyond Environmental Law: Policy Proposals for a Better Environmental Future, Alyson Flournoy and David Driesen, eds. (Cambridge University Press, forthcoming 2010)

Chapter: The Constitution and Our Debt to the Future

April 11, 2009

Copyright 2009 by Rena Steinzor--Please do not cite, quote, or copy without express permission of author.

if they would have comparable effects. Opponents of NELA could argue that unless the federal government subsidized the costs of these consequences, the new law should be read as purely regulatory with respect to private conduct, and therefore not involving the exercise of taxing or spending authority. Any number of other legislative formulations that seek to protect future generations could raise comparable questions.

Article I, Section 8 concludes that Congress has the power:

To make all Laws which shall be necessary and proper for carrying into Execution the foregoing Powers, and all other Powers vested by this Constitution in the Government of the United States, or in any Department or Officer thereof.

The courts have given Congress wide latitude in designing taxes and spending (e.g., state grants in aid) to include prescriptions that affect behavior of either the taxpayer or the recipient of federal largesse. ${ }^{77}$ How far they would defer in cases where spending is accompanied by regulation that affects the conduct of private parties is obviously an issue that must be resolved if and when we make the shift in constitutional doctrine. Supporters of NELA and similar next generation proposals would urge the most generous leeway, pointing out the very large sums the federal government is spending — and the even larger sums it would be required to spend—if these prohibited actions continued.

Putting these arguments together, then, the strong advantages of grounding the protection of public health and natural resources in the concept of the government's affirmative responsibilities to safeguard the quality of life in a civil society would best be served by recognition of a federal police power anchored on the General Welfare Clause. There remains the question of whether this power, or authority, can traverse the long distance to becoming a

77 See, generally, CHEMERINSKY, supra note 52, at 275-81. 
Beyond Environmental Law: Policy Proposals for a Better Environmental Future, Alyson Flournoy and David Driesen, eds. (Cambridge University Press, forthcoming 2010)

Chapter: The Constitution and Our Debt to the Future

April 11, 2009

Copyright 2009 by Rena Steinzor--Please do not cite, quote, or copy without express permission of author.

judicial enforceable right. For the foreseeable future, as explained in the next section, I think it

cannot. The proposition that the Constitution grants Congress authority to provide for the

general welfare of the people is not based on any notion that the people, or nature for that matter, have a judicially enforceable "right" to such protection. If the people are not satisfied with how Congress carries out this mission, their remedy is at the ballot box, not in the courts.

\section{Part V: The Affirmative Constitution}

\section{A. Negative Verus Affirmative Rights}

Mid-way through the Reagan Administration, long-simmering tensions among constitutional experts erupted into public view. The conflict, which is ongoing, pits conservatives who view the Constitution as primarily important for the "negative" rights it affords individuals against liberals who read "affirmative" rights into the text. ${ }^{78}$ A full exposition of this extensive debate is beyond the scope of this chapter. Nevertheless, locating my admittedly ambitious theory on the progressive end of this evolving constitutional scholarship should help readers evaluate it further.

The debate began in 1985 when then Attorney General Edwin Meese gave a speech to the American Bar Association articulating the theory of "originalism," an approach to interpreting the Constitution that views the Constitution as an immutable, transcendent law that is not subject to evolving, arguably inconsistent interpretations. ${ }^{79}$ Unless a proponent of a constitutional theory can provide substantial evidence that the Framers of the document intended for it to be

\footnotetext{
78 For an incisive summary of this literature, see Robin West, Progressive and Conservative Constitutionalism, 88 Mich. L. REV. 641 (1989-1990) [hereinafter Progressive and Conservative Constitutionalism]. See also, Robin West, The Aspirational Constitution, 88 Nw. U. L. REV. 241 (1993-1994) [hereinafter Aspirational Constitution]. 79 Speech by Attorney General Edwin Meese III before the American Bar Association, Washington, D.C., July 9, 1985, available at http://www.fed-soc.org/resources/id.49/default.asp.
} 
Beyond Environmental Law: Policy Proposals for a Better Environmental Future, Alyson Flournoy and David Driesen, eds. (Cambridge University Press, forthcoming 2010)

Chapter: The Constitution and Our Debt to the Future

April 11, 2009

Copyright 2009 by Rena Steinzor--Please do not cite, quote, or copy without express permission of author.

read the way they think we should read it today, the theory is rejected. Judges should not substitute their personal biases or policy choices for a careful study of what the Constitution's Framers had in mind.

Conservative commentators on the bench and in academia have embraced the doctrine, and it has become a central tenet for at least four Supreme Court Justices (Alito, Roberts, Scalia, Thomas), as well as countless judges in the lower courts. Originalism has prompted conservatives--and liberals seeking to persuade conservative judges and policymakers--to search through the documents contemporary to the Constitution, especially the Federalist Papers, as well as the history books to support claims that the Framers in their wisdom intended the result they advocate. Professor Parmet's careful exposition of the Framers' awareness of Massachusetts vaccine laws, discussed earlier, is an example of this kind of analysis. ${ }^{80}$

Supreme Court Justice William Brennan responded to General Meese in a speech at Georgetown University a few months later:

We current Justices read the Constitution in the only way that we can: as Twentieth Century Americans. We look to the history of the time of framing and to the intervening history of interpretation. But the ultimate question must be, what do the words of the text mean in our time. For the genius of the Constitution rests not in static meaning it might have had in a world that is dead and gone but in the adaptability of its great principles to cope with current problems and current needs. ${ }^{81}$

His views have been reiterated by progressive or liberal academics and judges, perhaps most notably by Justice Stephen Breyer in his 2005 book Active Liberty Interpreting, Our Democratic Constitution. ${ }^{82}$ Under this alternative view, the Constitution establishes a framework for the

\footnotetext{
80 Health Care and the Constitution, supra note 52.

81 Justice William J. Brennan, Jr., Speech to the text and Teaching Symposium, Georgetown University, Washington, D.C. Oct. 12, 1985, available at http://ww.fed-soc.org/resources/id.50/default.asp.

82 STEPHEN BREYER, ACTIVE LIBERTY, INTERPRETING OUR DEMOCRATIC CONSTITUTION (2005).
} 
Beyond Environmental Law: Policy Proposals for a Better Environmental Future, Alyson Flournoy and David Driesen, eds. (Cambridge University Press, forthcoming 2010)

Chapter: The Constitution and Our Debt to the Future

April 11, 2009

Copyright 2009 by Rena Steinzor--Please do not cite, quote, or copy without express permission of author.

most successful system of government in human history, but its statement of generalized principles must be interpreted in a flexible way to resolve challenges that the Framers could not have anticipated. The most important guidance for judges is their informed consideration of the shifting values shared by the American public, along with the consistent commitment to the protection of minority rights that motivated the Framers to establish a constitutional republic rather than a direct democracy.

Not surprisingly, because these discussions have revolved around judicial interpretations of the First, Second, Fourth, Fifth, and Fourteenth Amendments, they have focused on government's obligations to avoid interfering with individual autonomy (or negative rights), as opposed to its responsibility to provide benefits for the people (or affirmative rights). For example, challenges to the exercise of state police powers are often brought by individuals placed under quarantine or compelled to undergo vaccination. ${ }^{83}$ Judicial efforts to balance the needs of the community against the Bill of Rights did not substantially diminish the notion that the states had substantial discretion to do what was necessary to protect the general public. ${ }^{84} \mathrm{~A}$ smattering of scholars have argued for the recognition of affirmative rights to fundamental needs like health care but have encountered heavy resistance from the academic establishment and the courts. $^{85}$

${ }^{83}$ See, e.g. Jacobson v. Massachusetts, 195 U.S. 11 (1905) (upholding mandatory vaccination law). ${ }^{84}$ Id.

${ }^{85}$ For commentary on both sides of the issue, see Frank I. Michelman, In Pursuit of Constitutional Welfare Rights: One View of Rawls' Theory of Justice, 12 U. PA. L. REV. 962 (1973); Frank B. Cross, The Error of Positive Rights, 48 UCLA L. REV. 857 (2001) 
Beyond Environmental Law: Policy Proposals for a Better Environmental Future, Alyson Flournoy and David Driesen, eds. (Cambridge University Press, forthcoming 2010)

Chapter: The Constitution and Our Debt to the Future

April 11, 2009

Copyright 2009 by Rena Steinzor--Please do not cite, quote, or copy without express permission of author.

The landmark case is DeShaney v. Winnebago County Department of Social Services, ${ }^{86}$ which concerned the tragic story of four-year-old Joshua DeShaney who was so severely beaten by his father that he became profoundly retarded. The lawsuit was brought by his mother, who asserted that county authorities had twice returned Joshua to the custody of his father despite their awareness that Joshua was victim of repeated, severe physical abuse in his father's house. These actions violated Joshua's rights under the Fourteenth Amendment and entitled him to recovery under 42 U.S.C. §1983, the civil rights statute granting a cause of action against government officials who act outside the scope of their authority. Lower courts had rejected these claims. However, the Third Circuit held in a similar case that once a state or local government learns of abuse, and undertakes to protect a child from such danger, it forms a special relation that imposes an "affirmative constitutional duty" to provide adequate protection. $^{87}$ Six state attorneys general, the National Association of Counties, and the National School Boards Association filed amicus briefs in the DeShaney case, warning of the floodgates that would open if the Court put a foot wrong by suggesting that the states assumed an obligation to keep people like Joshua safe whenever the social service systems produced decisions about their lives. The Supreme Court granted certiorari to address this conflict in the circuits.

Acknowledging that the facts of the case elicited "natural sympathy," the majority noted that "before yielding to that impulse, it is well to remember once again that the harm was inflicted not by the State of Wisconsin, but by Joshua’s father.”88 Because the county had no “constitutional duty” to protect Joshua, its failure to do so, "although calamitous in hindsight,” is

\footnotetext{
86489 U.S. 189 (1989).

87489 U.S. at 194. The Third Circuit case was Estate of Baily by Oare v. County of York, 768 F.2d 503 (1985).

88489 U.S. at 202-03.
} 
Beyond Environmental Law: Policy Proposals for a Better Environmental Future, Alyson Flournoy and David Driesen, eds. (Cambridge University Press, forthcoming 2010)

Chapter: The Constitution and Our Debt to the Future

April 11, 2009

Copyright 2009 by Rena Steinzor--Please do not cite, quote, or copy without express permission of author.

not a violation of the Due Process Clause. ${ }^{89}$ Justice Brennan, writing in dissent for Justices Marshall and Blackmun, significantly did not challenge the majority’s view that “the Due Process Clause as construed by our prior cases creates no right to basic government services."90 But, he added, Joshua’s case did not present that question. Rather, Joshua suffered grave injury after the county had already taken action on more than one occasion to place the small child under the control of his father, thereby subjecting him to the possibility of abuse. If their actions were arbitrary, then Joshua and his mother should recover, and the case should be remanded to the trial court for examination of this issue. Given the extreme circumstances of the case, and the enormous pressure state and local governments can exert on courts by warning of the unforeseen consequences of creating affirmative rights, it is difficult to imagine that a majority of the Court would reverse this position any time soon.

Conditioning the argument for recognition of a federal police power on the acknowledgment that the Constitution grants Congress authority to take action but does not confer on individual citizens a judicially enforceable right to such protections has the great advantage of neutralizing a central assertion of the originalists. It would be a bad thing if unelected federal judges undertook the difficult job of deciding when and how to deploy the government's limited resources to combat such extensive threats. However, as Professor Robin West has argued persuasively in other contexts, the notion that judges have the exclusive prerogative to define the obligations of government is one of the most unfortunate results of a deeply conservative trend in legal scholarship. ${ }^{91}$

\footnotetext{
89489 U.S. at 201.

90489 U.S. 203-04.

91 Robin West, Unenumerated Duties, 9 U. PA. J. Const. L. 221 (2006) [hereinafter Unenumerated Duties].
} 
Beyond Environmental Law: Policy Proposals for a Better Environmental Future, Alyson Flournoy and David Driesen, eds. (Cambridge University Press, forthcoming 2010)

Chapter: The Constitution and Our Debt to the Future

April 11, 2009

Copyright 2009 by Rena Steinzor--Please do not cite, quote, or copy without express permission of author.

\section{B. The Aspirational Constitution}

If judges are not the sole source of constitutional interpretation and should not control— literally or by implication—how other branches read its affirmative grants of authority, how should Congress interpret its responsibilities under the General Welfare Clause? Professor West has argued persuasively that the Constitution creates positive obligations to pass laws that will protect citizens against environmental threats. ${ }^{92}$ She points to the writings of Thomas Hobbes, John Locke, Thomas Paine, and, more recently, John Rawls in defining the nature and scope of those responsibilities. She accepts the DeShaney holding as definitive at the same time that she dismisses it as irrelevant to Congress' quest to define its affirmative role.

Professor West further argues that the American people believe in the idea that Congress has affirmative duties, and are far more concerned about its failure to carry out those duties than they are about the government's interference with the individual rights that so preoccupy constitutional scholars:

The worry increasingly voiced by American citizens, particularly in Katrina's wake, is that our domestic politics and the state that is its product have become too wan, not too voracious, even as our foreign policies have become monstrously outsized. Our shrunken state, incapable of either preparing for or mounting an adequate response to a hurricane, incapable of repairing deteriorating bridges or crumbling schools, incapable of responding to public health crises or to a dangerously warming climate, seems, to many of our co-citizens, to be in breach of the most basic, fundamental duties central to a sensible construal of virtually any social compact. Thus, where lawyers look at our government and see the 'empire of force' of which Weil spoke, in violation of any number of constitutional norms, many of our co-citizens see, at best, sloth - an empire that is failing or willfully refusing to live up to its most basic obligations. ${ }^{93}$

\footnotetext{
92 Id.

93 Robin West, Ennobling Politics in LAW AND DEMOCRACY IN THE EMPIRE OF FORCE (H. Jefferson Powell \& James Boyd White, eds., Ann Arbor, Mich.: Univ. of Michigan Press forthcoming), available at http://papers.ssrn.com/sol3/papers.cfm?abstract_id=1172204 (visited on March 28, 2009).
} 
Beyond Environmental Law: Policy Proposals for a Better Environmental Future, Alyson Flournoy and David Driesen, eds. (Cambridge University Press, forthcoming 2010)

Chapter: The Constitution and Our Debt to the Future

April 11, 2009

Copyright 2009 by Rena Steinzor--Please do not cite, quote, or copy without express permission of author.

Time will tell whether a Democratic Congress and the Obama Administration will respond to these deep-seated perceptions of government inadequacies or whether they will shrink from these challenges in the face of strident charges that protections will cost too much and will drown our children in debt. It is no small irony that with respect to the breakthrough proposals discussed in this chapter and this book, nothing less than our children’s future is on the line. Consistency may be the hobgoblin of a small mind, but the profound inconsistencies between these arguments should feature prominently in future debates. We may think we cannot afford to deal with climate change and sustainability but our children certainly will not be able to afford these problems if we do not.

\section{Conclusion}

Despite their implicit commitment to precedent and a stable interpretation of the Constitution, General Meese and other originalists would be compelled to acknowledge that the Supreme Court has made some stunning, 180-degree turns in its history. In 1896, Plessy v. Ferguson upheld the "separate but equal" doctrine in the context of railway travel, ${ }^{94}$ only to rectify this disgrace 58 years later in Brown v. Board of Education of Topeka, Shawnee County, Kansas. $^{95}$ Yet the Constitution that existed in 1896 was the same as the Constitution that existed in 1954. What had changed were the hearts, minds, and perceived social imperatives of the justices appointed to safeguard it. At this moment on earth, with the planet's future literally hanging in the balance, it may be time for a similar Constitutional moment.

If we stick with Commerce Clause analysis, giving economists free rein to forecast future markets in commodities like clean air and clean water, we can justify incremental but significant

94163 U.S. 537 (1896).

95347 U.S. 483 (1954). 
Beyond Environmental Law: Policy Proposals for a Better Environmental Future, Alyson Flournoy and David Driesen, eds. (Cambridge University Press, forthcoming 2010)

Chapter: The Constitution and Our Debt to the Future

April 11, 2009

Copyright 2009 by Rena Steinzor--Please do not cite, quote, or copy without express permission of author.

changes. The problem with these projections is that the economic value of natural resources left in trust for future generations diminishes to zero over time. Consequently, traditional economic analysis militates against preserving environmental quality for future generations. Supporters of a National Environmental Legacy Act and similar proposals will seldom win a numbers game unless they limit their preservation goals to a severely constrained short-term.

If, on the other hand, we read the Constitution as embodying additional values beyond preservation of the marketplace, the horizon of change may well be extended beyond where we already see. The National Environmental Legacy Act and similar breakthrough laws, all of which are necessary to avert the worst consequences of climate change, could be based on the principle of preserving the general welfare that was embraced by the Framers and remains central to Americans' understanding of the rule of law today. Had the justices serving on the Supreme Court in the post-industrialization era been less timid, or less focused on shielding the marketplace from government interference, they might well have considered whether the Constitution's text provided additional authority to protect public health, safety, and the environment. 